\title{
PEMAHAMAN MODEL PEMBELAJARAN BERBASIS SCL PADA MATAKULIAH STRUKTUR\& KONSTRUKSI
}

\author{
Eddy Prianto*), Eddy Hermanto dan Hendro Trilistyo \\ ${ }^{*}$ Departemen Arsitektur, Fakultas Teknik, Universitas Diponegoro, \\ Jl. Prof. Soedarto, SH, Kampus Undip Tembalang, Semarang, Indonesia
}

\begin{abstract}
Abstrak
Sejauh ini, pola pembelajaran utama pada jurusan arsitektur adalah system pembelajaran kelas dan tugas lapangan/kasus yang mewarnai setiap matakuliah di kurikulum prodi S1-Arsitektur. Ketranpilan yang dilandasi pola piker/konsep akademis adalah modal yang diberikan bagi calon arsitek setelah lulus dari pendidikan ini. Dengan adanya pola perubahan pembelajaran TCL ke SCL, salah satunya memberikan porsi dosen bukan lagi memeiliki peran utama dalam menyampaikan ilmunya, namun kini berposisi sebagai fasilitator. Bagaimana dengan penerapannya yang ada di matakuliah Struktur dan Konstruksi di Jurusan Arsitektur Undip ini ?

Terdapat 10 model pembelajaran berbasis SCL ini, model mana yang telah diterapkan pada perkulian ini dan adakah ada peluang alternative lain dalam pengaplikasian di matakuliah ini? Sebenarnya pola atau model yang dilakukan secara paker bertema evaluasi dan pengembangan pembelajaran model SCL ini sudah saatnya untuk dikaji pada semua matakuliah inti di jurusan arsitektur FT undip ini.

Obyek matakuliah yang kami amati tentunya akan lebih mudah pada matakuliah yang kami ampu atau kami sebagai tim teaching didalamnya, yaitu matakuliah Struktur dan Konstruksi, terlebih fokos pada tahapan ini, diawali pada Struktur dan Konstruksi SEMESTER IV.

Peminat pendidikan arsitektur Undip dari tahun ke tahun selalu meningkat, salah satunya adalah peminat dasi aspek gender perempuan yang mencapai peningkatan dari $20 \% \mathrm{ke} 60 \%$, namun tidak signifikan terhadap pemahamannya pada model pembelajaran SCL di matakuliah struktur dan konstruksi semester 4. Tingkat pemahaman metode SCL dalam penelitian ini terbukti dipengaruhi oleh lama studi peserta yang mengambil matakuliah, artinya angkatan lama lebih paham model ini dibanding dengan angkatan baru pada matakuliah yang sama-sama diambilnya. Namun setelah dilakukan penjelasan / sosialisasi metode pembelajaran SCL ini secara singkat pada salah satu sesion pembelajaran di matakuliah Strukon 4 ini, pada rekapitulasi tahap berikutnya memberikan dampak positif bahwa sebanyak 86\% persen dari seluruh responden menyatakan menyukai pembelajran SCL ini. Dan secara urutan dari 10 (sepuluh) model pembelajaran SCL yang di sukai adalah Model Simulasi, Project-Based Learning (PjBL) dan Problem-Based Learning/Inquiry (PBL/I).
\end{abstract}

Keywords: Struktur\&Konstruksi, SCL, JAFT-UNDIP, Project-Based-Learning

\section{Pendahuluan}

Kurikulum Berbasis Kompetensi telah dirumuskan sejak tahun 2004 dan terus oleh Direktrat Jenderal pendidikan Tinggi RI dan pensosialisasiaan dari pihak Universitas Diponegoro melalui LP2MP Undipjuga telah dilakukan beberapa tahun yang lalu. Dari berbagai informasi bahwa sebanyak sekitar 800 orang dosen perwakilan dari 372 perguruan tinggi telah di latih dengan harapan telah berhasilt dideseminasikan dan menggunakan pengetahuan KBK di pembelajaran di perguruan tinggi. Dari hasil pemantauan terhadap implementasi KBK tahun 2007 oleh direktorat jenderal pendidikan tinggi, ternyata baru sekitar $60 \%$ peserta pelatihan telah menerapkan hasil pelatihan dengan berbagai tingkatan (Direktorat Akademik, 2008).
Bagaimana dengan yang ada di Undip? Dan bagaimana yang ada di Fakultas Teknik, terlebih khusus pembelajaran yang ada di Program Studi S1 Arsitektur Fakultas Teknik? Sebagaimana kita ketahui bersama salah satu program kerja dari LP2MP Undip adalah aspek pelatihan yang terkait dengan pengajaran, dan salah satunya materi tentang kurikulum berbasis Kompetensipun telah beberapa tahun ini dilakukan, dan peserta dari para dosen dari berbagai program studi di 11 fakultaspun juga tidak sedikit yang telah diberi pelatihan. Bagimana aplikasi dan evaluasi dari penerapan pembelajaran pola ini, merupakan pertanyan besar bagi kita semua.

Sejauh ini, pola pembelajaran utama pada jurusan arsitektur adalah system pembelajaran kelas dan tugas lapangan/kasus yang mewarnai setiap matakuliah di 
kurikulum prodi S1-Arsitektur. Ketranpilan yang dilandasi pola piker/konsep akademis adalah modal yang diberikan bagi calon arsitek setelah lulus dari pendidikan ini.

Kompetensi yang diharapkan dari lulusan prodi S1-Arsitektur harus tersurat dan tersitrat dalam setiap pembelajaran di ruangan kelasnya, tak terlepas dari matakuliah Struktur dan Konstruksi. Matakuliah ini diberikan pada setiap jenjang semester dari awal hingga akhir, karena produk karya arsitektur pasti tidak lepas dari aspek ini.

Dan kami adalah salah satu peserta pelatihan tersebut merasa perlu mengaplikasikan dengan tepat, minimal pada matakuliah yang kami diampu, pengembangan dan pengevaluasiaan proses pembelajaran berbasis SCL ini, dimana hal ini merupakan ujud dari keberhasilan pendidikan berbasis kompetensi ini. Kami yakini, bahwa pelaksanaan yang ada tentunya tidak sama sekali lepas dari proses pembelajaran model seperti ini (nama bisa beda tapi prinsipnya mungkin sama), namun untuk mengetahui peta atau karakter pembelajaran yang dimaksud tersebutlah yang melatar belakangi dilakukan penelitian ini, khusunya pada matakuliah yang ,strategis ${ }^{\text {ee }}$ memberi warna pada pendidikan arsitektur dan diharapkan pula langkah ini bisa menjadi multi-plier efekk pada matakuliah lain khususnya pada Jurusan Arsitektur Fakultas Teknik (JAFT).

Aplikasi dari pembelajaran pada matakuliah Struktur dan Konstruksi yang telah berjalan hingga sekian tahun umur dari program studi S1 Arsitektur, pastilah berkembang menyesuaikan tuntutan jaman, tekbnologi dan pasar. Itulah salah satu konsep pembelajaran KBK yang diharapkan diaplikasikan pada perkuliahan ini. Sejauh ini, silabus dari matakuliah Struktur dan Konstruksi tak lepas dari image membuat tugas pengamatan dan maket konstruksi bangunan arsitektur bangunan sesuai karakter tingkatan bangunan. Apakah kesemuanya yang berjalan itu telah sesuai dengan salah satu model pembelajaran berbasis KBK aau pemodelan pembelajaran yang SCL ? Kegunaan dari out pembelajaran yang ada sebenarnya tidak lepas dari tujuan menunju kompetensinya, yaitu salah satunya mampu, paham dan mengerti tentang teknis arsitektural pembangunan gedung khususnya di Indonesia ( Ditjen PU, 1997) (Lippmeier, 1994), (Men PP, 2002)

Pada penelitian ini dilakukan kajian akademis terhadap pelaksanaan pembelajaran mata kuliah Struktur dan Konstruksi di JAFT dan kemungkinan eksplorasi/pengembangan alternative ke 10 model model SCL.

Berpijak pada hasil penerapan pembelajaran yang ada di JAFT Undip, khususnya pada matakuliah Struktur dan Konstruksi IV sebelumnya dan materi Workshop Pelatihan penyusunan Kurikulum berbasis KBK yang diselenggarakan oleh LP2MP bagi dosendosen di lingkungan Universitas Diponegoro dan hasil penelitian ini nantinya, diharapkan akan jadi salah satu bahan masukan kajian pelaksanaan pembelajaran matakuliah Struktur dan secara khusus pada semester IV, ataupun bahan masukan aplikasi dari 10 model pembelajaran SCL bagi matakuliah lainnya di JAFT (LP2MP, 2014).

Dari hasil penelitian ini sendiri diharapkan mampu menyumbang metode pembelajaran berbasis SCL umum, atau bahkan jadi suatu langkah awal suatu panduan untuk kajian dan aplikasinya pada perkuliahan lainnya.

Tujuan dari penelitian ini adalah 1). Melakukan studi analisis pelaksanaan model pembelajaran berbasis SCL pada matakuliah Struktur dan Konstruksi (dengan kasus matakuliah Strukon IV) yang ada di prodi S1 Arsitektur FT dan 2) Dan pengembangannya, kami akan menganalisa 10 model pembelajaran berbasis SCL ini yang mana yang diminati peserta kuliah.

\section{Kajian Teori \\ Kondisi pembelajaran di perguruan tinggi saat ini}

Proses pembelajaran yang banyak dipraktekkan sekarang ini sebagian besar berbentuk penyampaian secara tatap muka (lecturing), searah. Pada saat mengikuti kuliah atau mendengarkan ceramah, mahasiswa akan kesulitan untuk mengikuti atau menangkap makna esensi materi pembelajaran, sehingga kegiatannya sebatas membuat catatan yang kebenarannya diragukan. Pola proses pembelajaran dosen aktif dengan mahasiswa pasif ini efektifitasnya rendah, dan tidak dapat menumbuhkembangkan proses partisipasi aktif dalam pembelajaran.

Keadaan ini terjadi sebagai akibat elemen-elemen terbentuknya proses partisipasi yang berupa,

- dorongan untuk memperoleh harapan (effort),

- kemampuan mengikuti proses pembelajaran, dan

- $\quad$ peluang untuk mengungkapkan materi pembelajaran yang diperolehnya di dunia nyata/masyarakat tidak ada atau sangat terbatas. Intensitas pembelajaran mahasiswa umumnya meningkat (tetapi tetap tidak efektif), terjadi pada saat-saat akhir mendekati ujian. Akibatnya mutu materi dan proses pembelajaran sangat sulit untuk diakses.

Dosen menjadi pusat peran dalam pencapaian hasil pembelajaran dan seakan-akan menjadi satusatunya sumber ilmu. Perbaikan pola pembelajaran ini telah banyak dilakukan dengan kombinasi lecturing, tanya-jawab, dan pemberian tugas, yang kesemuanya dilakukan berdasarkan "pengalaman mengajar" dosen yang bersangkutan dan bersifat trial-error.

Luaran proses pembelajaran tetap tidak dapat diakses, serta memerlukan waktu lama pelaksanaan perbaikannya. Pola pembelajaran di perguruan tinggi 
yang berlangsung saat sekarang perlu dikaji untuk dapat dipetakan pola keragamannya. Oleh karenanya perlu dilakukan perubahan dalam proses dan materi pembelajaran di perguruan tinggi tidak lagi berbentuk Teacher-Centered Content-Oriented (TCCO), tetapi diganti dengan menggunakan prinsip Student-Centered Learning (SCL) yang disesuaikan dengan keadaan perguruan tingginya (Direktorat Akademik, 2008).
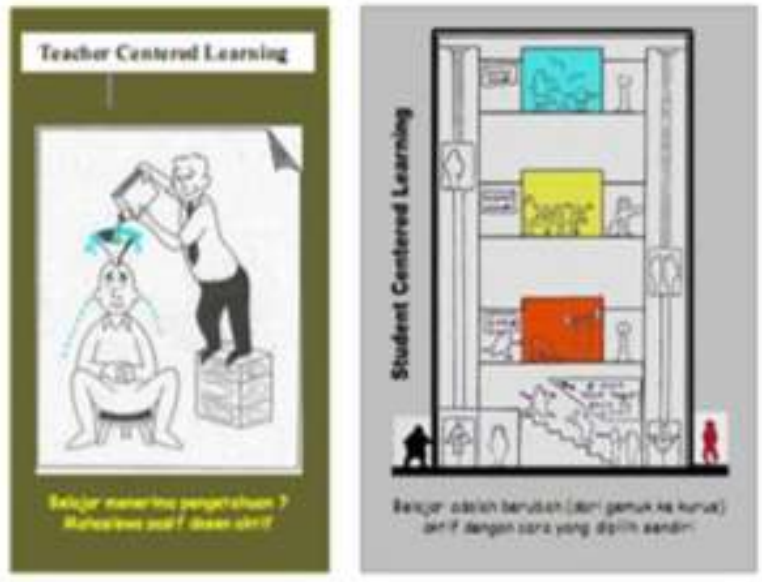

Gambar 1 : Ilustrasi perbedaan TCL dan SCL

\section{Perubahan dari "tcl (tcco)" ke arah "scl"}

Pola pembelajaran yang terpusat pada dosen seperti yang dipraktekkan pada saat ini kurang memadai untuk mencapai tujuan pendidikan berbasis kompetensi. Berbagai alasan yang dapat dikemukakan antara lain adalah (Direktorat Akademik, 2008).:

- $\quad$ Perkembangan IPTEK dan Seni yang sangat pesat dengan berbagai kemudahan untuk mengaksesnya merupakan materi pembelajaran yang sulit dapat dipenuhi oleh seorang dosen,

- Perubahan kompetensi kekaryaan yang berlangsung sangat cepat memerlukan materi dan proses pembelajaran yang lebih fleksibel,

- Kebutuhan untuk mengakomodasi demokratisasi partisipatif dalam proses pembelajaran di perguruan tinggi. Oleh karena itu pembelajaran ke depan didorong menjadi berpusat pada mahasiswa (SCL) dengan memfokuskan pada tercapainya kompetensi yang diharapkan.

Hal ini berarti mahasiswa harus didorong untuk memiliki motivasi dalam diri mereka sendiri, kemudian berupaya keras mencapai kompetensi yang diinginkan. Ketiga alasan pergeseran pembelajaran yang diuraikan diatas merupakan alasan diluar esensi proses pembelajaran itu sendiri.

Bila ditinjau esensinya, pergeseran pembelajaran adalah pergeseran paradigma, yaitu paradigma dalam cara kita memandang pengetahuan, paradigma belajar dan pembelajaran itu sendiri. Paradigma lama memandang pengetahuan sebagai sesuatu yang sudah jadi, yang tinggal dipindahkan ke orang lain/mahasiswa dengan istilah transfer of knowledge. Paradigma baru, pengetahuan adalah sebuah hasil konstruksi atau bentukan dari orang yang belajar. Sehingga belajar adalah sebuah proses mencari dan membentuk/ mengkonstruksi pengetahuan, jadi bersifat aktif, dan spesifik caranya. Sedangkan dengan paradigma lama belajar adalah menerima pengetahuan, pasif, karena pengetahuan yang telah dianggap jadi tadi tinggal dipindahkan ke mahasiswa dari dosen, akibatnya bentuknya berupa penyampaian materi (ceramah). Dosen sebagai pemilik dan pemberi pengetahuan, mahasiswa sebagai penerima pengetahuan, kegiatan ini sering dinamakan pengajaran. Dengan pola ini perencanaan pengajarannya (GPPP dan SAP) lebih banyak mendeskripsikan kegiatan yang harus dilakukan oleh pengajar, sedang bagi mahasiswa perencanaan tersebut lebih banyak bersifat instruksi yang harus dijalankan. Konsekuensi paradigma baru adalah dosen hanya sebagai fasilitator dan motivator dengan menyediakan beberapa strategi belajar yang memungkinkan mahasiswa (bersama dosen) memilih, menemukan dan menyusun pengetahuan serta cara mengembangkan ketrampilannya (method of inquiry and discovery). Dengan paradigma inilah proses pembelajaran (learning process) dilakukan. Dengan ilustrasi dibawah ini akan lebih jelas perbedaan TCL dengan SCL.

\section{Model-model pembelajaran ke arah "scl" Small Group Discussion}

Diskusi adalah salah satu elemen belajar secara aktif dan merupakan bagian dari banyak model pembelajaran SCL yang lain, seperti CL, CbL, PBL, dan lain-lain. Mahasiswa peserta kuliah diminta membuat kelompok kecil (5 sampai 10 orang) untuk mendiskusikan bahan yang diberikan oleh dosen atau bahan yang diperoleh sendiri oleh anggota kelompok tersebut (Direktorat Akademik, 2008)..

Dengan aktivitas kelompok kecil, mahasiswa akan belajar:

(a) Menjadi pendengar yang baik;

(b) Bekerjasama untuk tugas bersama;

(c) Memberikan dan menerima umpan balik yang konstruktif;

(d) Menghormati perbedaan pendapat;

(e) Mendukung pendapat dengan bukti; dan

(f) Menghargai sudut pandang yang bervariasi (gender, budaya, dan lain-lain).

Adapun aktivitas diskusi kelompok kecil dapat berupa:

(a) Membangkitkan ide; 
(b) Menyimpulkan poin penting;

(c) Mengases tingkat skill dan pengetahuan;

(d) Mengkaji kembali topik di kelas sebelumnya;

(e) Menelaah latihan, quiz, tugas menulis;

(f) Memproses outcome pembelajaran pada akhir kelas;

(g) Memberi komentar tentang jalannya kelas;

(h) Membandingkan teori, isu, dan interpretasi;

(i) Menyelesaikan masalah; dan

(j) Brainstroming.

\section{Simulasi/Demonstrasi}

Simulasi adalah model yang membawa situasi yang mirip dengan sesungguhnya ke dalam kelas. Misalnya untuk mata kuliah aplikasi instrumentasi, mahasiswa diminta membuat perusahaan fiktif yang bergerak di bidang aplikasi instrumentasi, kemudian perusahaan tersebut diminta melakukan hal yang sebagaimana dilakukan oleh perusahaan sesungguhnya dalam memberikan jasa kepada kliennya, misalnya melakukan proses bidding, dan sebagainya. Simulasi dapat berbentuk:

(a) Permainan peran (role playing). Dalam contoh ini, setiap mahasiswa dapat diberi peran masing-masing, misalnya sebagai direktur, engineer, bagian pemasaran dan lain-lain;

(b) Simulation exercices and simulation games; dan

(c) Model komputer.

Simulasi dapat mengubah cara pandang (mindset) mahasiswa, dengan jalan:

(a) Mempraktekkan kemampuan umum, (missal komunikasi verbal \& nonverbal);

(b) Mempraktekkan kemampuan khusus;

(c) Mempraktekkan kemampuan tim;

(d) Mengembangkan kemampuan menyelesaikan masalah

(problem-solving);

(e) Menggunakan kemampuan sintesis; dan

(f) Mengembangkan kemampuan empati.

\section{Discovery Learning (DL)}

DL adalah metode belajar yang difokuskan pada pemanfaatan informasi yang tersedia, baik yang diberikan dosen maupun yang dicari sendiri oleh mahasiswa, untuk membangun pengetahuan dengan cara belajar mandiri.

\section{Self-Directed Learning (SDL)}

SDL adalah proses belajar yang dilakukan atas inisiatif individu mahasiswa sendiri. Dalam hal ini, perencanaan, pelaksanaan, dan penilaian terhadap pengalaman belajar yang telah dijalani, dilakukan semuanya oleh individu yang bersangkutan. Sementara dosen hanya bertindak sebagai fasilitator, yang memberi arahan, bimbingan, dan konfirmasi terhadap kemajuan belajar yang telah dilakukan individu mahasiswa tersebut. Metode belajar ini bermanfaat untuk menyadarkan dan memberdayakan mahasiswa, bahwa belajar adalah tanggungjawab mereka sendiri. Dengan kata lain, individu mahasiswa didorong untuk bertanggungjawab terhadap semua fikiran dan tindakan yang dilakukannya.

Metode pembelajaran SDL dapat diterapkan apabila asumsi berikut sudah terpenuhi. Sebagai orang dewasa, kemampuan mahasiswa semestinya bergeser dari orang yang tergantung pada orang lain menjadi individu yang mampu belajar mandiri.

Prinsip yang digunakan di dalam SDL adalah:

(a) Pengalaman merupakan sumber belajar yang sangat bermanfaat;

(b) Kesiapan belajar merupakan tahap awal menjadi pembelajar mandiri; dan

(c) Orang dewasa lebih tertarik belajar dari permasalahan daripada dari isi matakuliah.

Pengakuan, penghargaan, dan dukungan terhadap proses belajar orang dewasa perlu diciptakan dalam lingkungan belajar. Dalam hal ini, dosen dan mahasiswa harus memiliki semangat yang saling melengkapi dalam melakukan pencarian pengetahuan

\section{Cooperative Learning (CL)}

CL adalah metode belajar berkelompok yang dirancang oleh dosen untuk memecahkan suatu masalah/kasus atau mengerjakan suatu tugas. Kelompok ini terdiri atas beberapa orang mahasiswa, yang memiliki kemampuan akademik yang beragam. Metode ini sangat terstruktur, karena pembentukan kelompok, materi yang dibahas, langkah-langkah diskusi serta produk akhir yang harus dihasilkan, semuanya ditentukan dan dikontrol oleh dosen. Mahasiswa dalam hal ini hanya mengikuti prosedur diskusi yang dirancang oleh dosen.

Pada dasarnya CL seperti ini merupakan perpaduan antara teachercentered dan student-centered learning. CL bermanfaat untuk membantu menumbuhkan dan mengasah:

(a) kebiasaan belajar aktif pada diri mahasiswa;

(b) rasa tanggungjawab individu dan kelompok mahasiswa;

(c) kemampuan dan keterampilan bekerjasama antar mahasiswa; dan

(d) keterampilan sosial mahasiswa.

\section{Collaborative Learning (CbL)}

$\mathrm{CbL}$ adalah metode belajar yang menitikberatkan pada kerjasama antar mahasiswa yang didasarkan pada konsensus yang dibangun sendiri oleh anggota 
kelompok. Masalah/tugas/kasus memang berasal dari dosen dan bersifat open ended, tetapi pembentukan kelompok yang didasarkan pada minat, prosedur kerja kelompok, penentuan waktu dan tempat diskusi/kerja kelompok, sampai dengan bagaimana hasil diskusi/kerja kelompok ingin dinilai oleh dosen, semuanya ditentukan melalui konsensus bersama antar anggota kelompok.

\section{Instruction (CI)}

CI adalah konsep belajar yang membantu dosen mengaitkan isi matakuliah dengan situasi nyata dalam kehidupan sehari-hari dan memotivasi mahasiswa untuk membuat keterhubungan antara pengetahuan dan aplikasinya dalam kehidupan sehari-hari sebagai anggota masyarakat, pelaku kerja profesional atau manajerial, entrepreneur, maupun investor. Sebagai contoh, apabila kompetensi yang dituntut matakuliah adalah mahasiswa dapat menganalisis faktor-faktor yang mempengaruhi proses transaksi jual beli, maka dalam pembelajarannya, selain konsep transaksi ini dibahas dalam kelas, juga diberikan contoh, dan mendiskusikannya. Mahasiswa juga diberi tugas dan kesempatan untuk terjunlangsung di pusat-pusat perdagangan untuk mengamati secara langsung proses transaksi jual beli tersebut, atau bahkan terlibat langsung sebagai salah satu pelakunya, sebagai pembeli, misalnya. Pada saat itu, mahasiswa dapat melakukan pengamatan langsung, mengkajinya dengan berbagai teori yang ada, sampai ia dapat menganalis faktor-faktor apa saja yang mempengaruhi terjadinya proses transaksi jual beli. Hasil keterlibatan, pengamatan dan kajiannya ini selanjutnya dipresentasikan di dalam kelas, untuk dibahas dan menampung saran dan masukan lain dari seluruh anggota kelas. Pada intinya dengan CI, dosen dan mahasiswa memanfaatkan pengetahuan secara bersama-sama, untuk mencapai kompetensi yang dituntut oleh matakuliah, serta memberikan kesempatan pada semua orang yang terlibat dalam pembelajaran untuk belajar satu sama lain.

\section{Project-Based Learning (PjBL)}

PjBL adalah metode belajar yang sistematis, yang melibatkan mahasiswa dalam belajar pengetahuan dan keterampilan melalui proses pencarian/penggalian (inquiry) yang panjang dan terstruktur terhadap pertanyaan yang otentik dan kompleks serta tugas dan produk yang dirancang dengan sangat hati-hati. Dalam pendidikan arsitektur, sering dilakukan survay lapangan pada gedung-gedung bertingkat karena didalamnya teraplikasi segala peraturan bangunan dan persyaratannya. (ditjen PU, 1997), (lippmeier, 1994), (men Permukiman, 2002), (prianto, 2007), (satwiko, 2005), (soegiyjanto, 1998), (szokolay, 1980)

\section{Problem-Based Learning/Inquiry (PBL/I)}

PBL/I adalah belajar dengan memanfaatkan masalah dan mahasiswa harus melakukan pencarian/penggalian informasi (inquiry) untuk dapat memecahkan masalah tersebut.

Pada umumnya, terdapat empat langkah yang perlu dilakukan mahasiswa dalam PBL/I, yaitu:

(a) Menerima masalah yang relevan dengan salah satu/beberapa kompetensi yang dituntut matakuliah, dari dosennya;

(b) Melakukan pencarian data dan informasi yang relevan untuk memecahkan masalah;

(c) Menata data dan mengaitkan data dengan masalah; dan

(d) Menganalis strategi pemecahan masalahPBL/I adalah belajar dengan memanfaatkan masalah dan mahasiswa harus melakukan pencarian/penggalian informasi (inquiry) untuk dapat memecahkan masalah tersebut.

\section{Alat dan bahan}

Secara prinsip, alat dan bahan dalam mencapai tujuan penelitian ini adalah : sumber referensi, terutama keterkaitan bangunan dengan konsumsi energinya dan iklim tropisnya ( Prianto, 2007), (Satwiko, 2005), (Soegijanto, 1998) dan (Szokolay, 1980), dokument kuesioner dan bahan pembutanan alat peraga, berupa maket, poster, slide. Sedangkan bahan untuk mendapatkan data primer ke lapangan maka dilakukan studi lapangan.

\section{Pembahasan}

Pembahasan ini di bedakan emnjadi dua tahap sebagaimana sesuai dengan tujuan penulisan ini.

Tahap pertama adalah pembahasan terkait dengan profil peserta kuliah matakuliah struktur konmstruksi 4 tahun 2015 dan tahap berikutnya, adalah sejauh mana peserta kuliah strukon 4 ini memahami metode pembelajaran SCL.

\section{Profil gender peserta kuliah :}

Peserta matakuliah Struktur dan Konstruksi semester 4 tahun 2015 berjumlah 161 mahasiswa dengan sebaran laki-laki dan pesempuan dapat dilihat pada tabel dibawah ini :

Dari data tersebut diatas, dapat dibaca bahwa di kelas A (terdiri dari kelas A1 dan A2) terdapat 77 peserta dan kelas B (terdiri dari kelas B1 dan B2) terdapat 84 peserta. Atau total peserta pada matakuliah strukon 4 tahun 2015 ini sebanyak 161 peserta, yang terdiri dari komposisi untuk mahasiswi sebanyak $61 \%$ (98/161) dan mahasiswa sebanyak 39\% (63/161). 


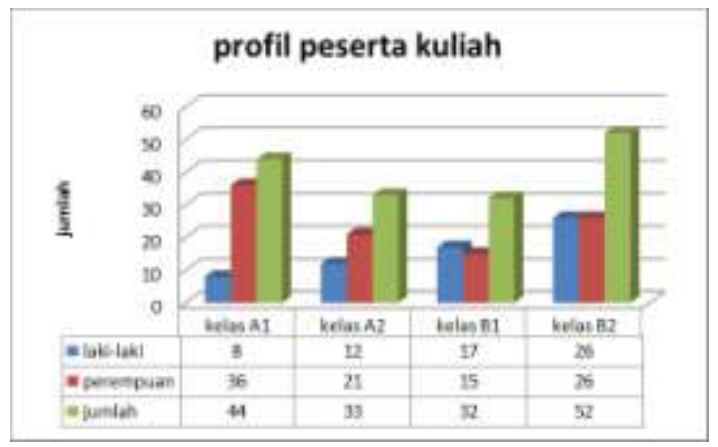

Gambar 2: Rekap peserta kuliah mk.strukon4 berdasarkan gender

Yang dimaksud status semester, adalah pengelompokan mahasiswa berdasarkan status semester yang diambil pada tahun 2015. Artinya pada matakuliah strukon4 ini, para pesertanya tidak hanya mereka yang berasal dari semester 4 (empat) saja, tapi juga dari mahasiswa semester genap lainnya (semester 04 dan 06).

Berbagai alasan terjadi, karena bagi mahasiswa yang masih di semester 02, mereka dapat mengambil kuliah ini, dikarenakan kelebihan sks dari standart normal tiap semesternya (sekitar 18-21 sks), sedangkan yang berada di semester 4 , bisa terjadi mereka mengulang untuk perbaikan nilai ataupun mereka belum pernah mengambil atau tidak lulus. Berikut profil pengelompokannya:

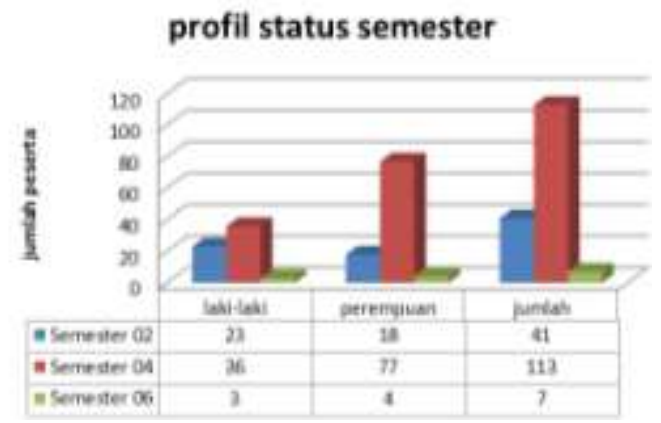

Gambar 3: Rekap peserta kuliah mk.strukon-4 berdasarkan status semester yang diambil

Dari tampilan grafik disebelah kiri, dapat dibaca bahwa peserta kuliah strukon4 terdiri dari :

- Angkatan 2014 (peserta semester 02), memiliki komposisi 25\% (41/161), dimana mereka pada semester yang sama juga sedang/harus mengambil matakuliah strukon02. Artinya dalam semester genap ini mereka mengambil dua materi trukon, yaiotu strukon2 dan 4 dengan materi penekanan struktur yang berbeda.

- Angkatan 2013 (peserta on going/semester 04), merupakan komposisi mayoritas karena matakuliah strukon4 memang berada pada semester 4. Dengan komposis 70\% (113/161), mereka memang berhak dan waktunya untuk mengambil matajuliah di semester 4 ini.

- Sedangkan untuk angkatan 2012 (peserta semester 06/ kakak kelas), hanya terdiri dari 5\% (7/161), dengan berbagai alas an mereka 'mengulang' mengambil matakuliah disemester ini.

Sedangkan pada grafik disebelah kanan menunjukan komposisi profil peserta kuliah berdasarkan klasifikasi berdasarkan gender :

- Angkatan 2014 (peserta semester 2) :

o Untuk gender laki-laki berkomposisi 23/41, atau sebanyak $56 \%$

o Sedangkan untuk gender perempuan $44 \%$.

- Angkatan 2013 (peserta on going/semester 4) :

o Untuk gender laki-laki berkoposisi 36/113 atau sebanyak $32 \%$ dan

o Under perempuan mencapai 77/113 (68\%), atau dua kali lipat disbanding gender laki-lakinya

- Sedangkan untuk angkatan 2012 (peserta semester 6/ kakak kelas) :

o Untuk gender laki-laki berkoposisi 3/7 atau sebanyak $43 \%$ dan

o Under perempuan mencapai 4/7 (57\%)

Tentunya pihak pengelola Jurusan arsitektur ataupun pengelola tingkat Fakultas/Universitas, memiliki data yang akurat tentang progress komposisi status gender yang mengikuti perkuliahan di Fakultas Teknik secara Umum dan khususnya jurusan arsitektur. Khusus pada peserta kuliah strukon4 tahun 2014 ini, gender perempuan mencapai $61 \%$ dan hampir merata prosentase tersebut untuk setiap angkatan yang mewakilinya. Bilamana dikaitkan dengan kemampuaan akademis, hal ini dapat disimpulkan dengan melihat angkatan baru (2014), bahwa gender perempuan lebih cerdas/berani untuk mengambil matakuliah strukon 4 yang bersamaan dengan strukon2 pada semester genap ini. Namun apakah pemahaman materi menujukan data yang signifikan ?. Gender perempuan mendominasi peserta kuliah di JAFT Undip.

\section{Pemahaman SCL}

Pendataan tahap kedua dari para mahasiswa, setelah dilakukan pendataan identitas masing-masing mahasiswa, adalah dilakukan pendataan pemahaman SCL ini. Data menunjukan 93\% (153/161) mahasiswa peserta kuliah, menyatakan tahu singkatan dari apakah itu SCL (cek gambar dibawah). Walau dalam evaluasi pemahamannya kami menggunakan istilah-istilah yang sedikit sulit/membingungkan, seperti : Student Central Leader, Student Central Learning, Study Central Leader, 
Study Central Learning, Student Centered Leader dan Student Centered Learning

\section{mengertikah istilah/ singkatan $\mathrm{SCL}$}
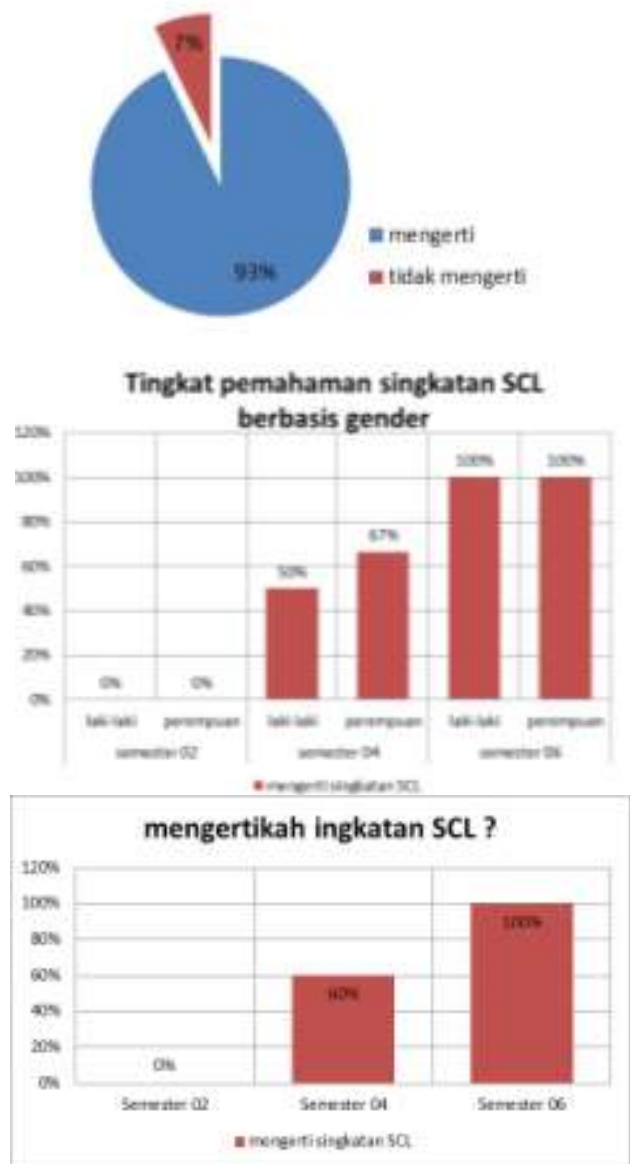

Gambar 4: Pemahaman singkatan SCL dari aspek pengelpokan status semester dan gender

Dari tampilan grafik disebelah kiri, dapat dibaca bahwa pemahaman istilah SCL pada peserta kuliah strukon4 tahun 2015 dalah sebagai berikut :

- Angkatan 2014 (peserta semester 02), mutlak peserta yang berasal dari angkatan 2014-, masih semester 02 tidak satupun yang tahu apa istilah SCL (0\%).

- Angkatan 2013 (peserta on going/semester 04), adalah peserta yang on-going/ semester berjalan memiliki $60 \%$ dari peserta yang paham/tahu arti SCL

- Sedangkan untuk angkatan 2012 (peserta semester 06/ kakak kelas), mutlak mengetahui istilah SCL (100\%).

Sedangkan pada grafik disebelah kanan menunjukan komposisi profil peserta kuliah berdasarkan klasifikasi berdasarkan gender :
-Angkatan 2014 (peserta semester 2) :

Baik untuk gender laki-laki maupun perempuan mutlak $0 \%$ tidak paham/tidak tahu. Hal ini seharusnya menjadi catatan pihak jurusan Arsitektur, bahwa pemahaman SCL tidak hanya ditemukan di matakuliah Strukon4 tapi aplikasinya pada seluruh matakuliah yang diajarkan di JAFT. Ketidak pahaman memiliki beberapa sebab, diantaranya mereka samasekali tidak tahu karaeana tidak ada sarana/fasiliotas bahkan dosen yang memberitahu pemahaman SCL.

- Angkatan 2013 (peserta on going/semester 4) :

Baik untuk gender laki-laki maupun perempuan masing-masing $50 \%$ paham dan tidak paham.

o Sedangkan untuk angkatan 2012 (peserta semester 6/ kakak kelas) :

o Baik untuk gender laki-laki maupun perempuan mutlak $100 \%$ paham.

Dari seluruh peserta matahuliah Strukon4 tahun 2014, yang terdiri dari beberapa angkatan, yaitu angkatan 2014, 2013 dan 2012, pada pertanyaan sejauh mana mereka memahami/mengerti istilah SCL, ternyata jawabannya 93\% mengerti. Hal ini sebenarnya tidaklah membuat sesuatu yang bermasalah. Namun 7\% sisanya, setelah dicek berdasarkan pengelpomokan angkatan, ternyata $100 \%$ peserta yang tidak paham adalah angkatan baru/ masih di semester 02. Mereka adalah mahasiswa terbaru setelah mengajali perkulihan semester gasal, seharusnya mereka harus diperkenalkan tentang metedode SCL tanpa harus mengalios seiring perkembangan/kemajuan pendididikan, artinya mereka dibiarkan dan mendapatkan informasi berdasarkan pengalaman setelah menjalani beberapa lama perkuliahan di jurusan arsitektur. Hal ini, senada karena makin lama telah mengeyam pendidikan arsitektur, mereka sadar adatu tidak disadari terbukti seperti angkatan 2012 ternyata 100\% paham arti SCL ini.

Angkatan baru banyak tidak memahami metode pembelajaran SCL.

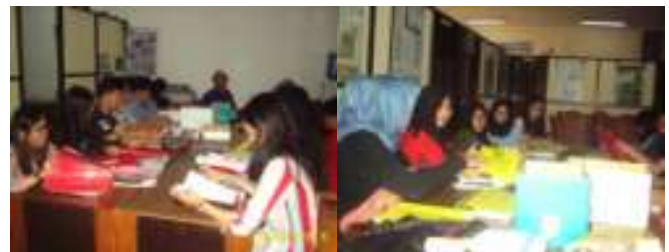

Gambar 5 : Suasana kegiatan diskusi bahan kuliah yang difasilitasi dosen

\subsection{Apakah saudara menyukai sistem pembelajaran berbasis SCL tersebut?}

Pada pertanyaan no.3 dari kuisener yang dibagikan ini, dilanjutkan dengan pemahaman apakah para peserta menyukai sistem pembelajaran SCL ini. Hal 
ini sebenarnya tidak hanya ditujukan pada mahasiswa peserta matakuliah strukon4 tahun 2014 saja, tapi ditujukan pada seluruh mahasiswa yang mengambil pendidikan arsitektur di Fakultas Teknik Undip ini. Memang akan lebih tepat, bilamana pertanyaan ini diajukan sebagai bahan evaluasi pada kelompok mahasiswa yang pernah tahu/ mendapatkan aplikasinya pembelajaran SCL. Tapi juga akan berguna, bilamana ditujunkan pada mahasiswa baru, agar kelak dapat direncanakan seberapa jauh kepentingan pendidikan metode SCL ini. Karana strukon semester 4 ini, pesertanya beragam, maka kami coba mendata hal teresebut. Dari 161 peserta yang terdiri dari 3 angkatan, ternyata data menunjukan bahwa $86 \%$ menyukai pembelajaran dengan metode SCL. Siapakah mereka?

\section{Menyukaikah pembelajaran $\mathrm{SCL}$ ?}


Menyukaikah pembelajaran SCL?

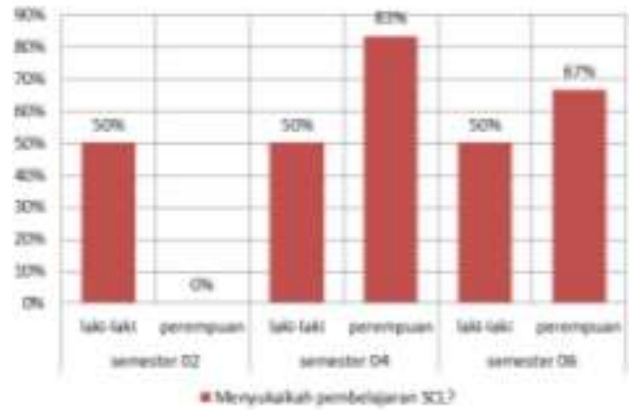

Gambar 6:Pembelajaran SCL dari sudut pandang mahasiswa
Dari tampilan grafik disebelah kiri, dapat dibaca bahwa tingkat menyukai metode pembelajaran SCL di tahun 2015 (bukan hanya untuk matakuliah strukon4) adalah sebagai berikut :

- Angkatan 2014 (peserta semester 02), hanya sebesar $20 \%$ dari total peserta dari angkatan ini yang menyukai pembelajaran SCL, walau didata sebelumnya, mereka seluruh angkatan ini tidak tahu apa arti SCL.

- Angkatan 2013 (peserta on going/semester 04), adalah peserta yang on-going/ semester berjalan memiliki $50 \%$ dari peserta yang menyukai metode pembelajaran SCL

- Sedangkan untuk angkatan 2012 (peserta semester 06/ kakak kelas), relative mengusai benar metode SCL ini dan $86 \%$ menyukai pembelajaran dengan metode ini. kami berharap bukan hanya untuk matakuliah strukon4 saja.

Sedangkan pada grafik disebelah kanan menunjukan komposisi profil peserta kuliah berdasarkan klasifikasi berdasarkan gender :

- Angkatan 2014 (peserta semester 2) :

o Untuk gender laki-laki ternyata hanya $50 \%$ yang menyukai metode pembelajaran SCL, tentunya sisanya tidak menyukai. Tapi karena mereka merupakan angkatan baru, interpretasi meyukai ataupun tidak tahu menahu perlu dilakukan penelitian lebih lanjut.

o Untuk gender perempuan 100\% mereka tidak menyukai pembelajaran SCL. Kembali lagi hal ini masih perlu dipertanyakan.

- Angkatan 2013 (peserta on going/semester 4) :

o Untuk gender laki-laki hanya $50 \%$ dari total peserta dari angkatan ini yang menyukai pembelajaran SCL

o Sedangkan untuk gender perempuan justru mencapai tingkat $86 \%$ menyukainya.

- Sedangkan untuk angkatan 2012 (peserta semester 6/ kakak kelas) :

o Untuk gender laki-laki hanya $50 \%$ dari total peserta dari angkatan ini yang menyukai pembelajaran SCL

o Sedangkan untuk gender perempuan juga hanya sekitar $67 \%$, relative lebih banyak disbanding lakilaki. Namun bilamana dibandingkan dengan angkatan 2013 seharusnya prosentasenya lebih tinggi untuk menyakinkan bahwa angkatan lama ini benar-benar menyukai atau tidak, atau data bertolak belakang dari sebelumnya, dimana mereka paham betul tapi mereka tidak mutlak menyukainya 
Hal yang positif dan negative dapat kita dapatkan dari data ini. Yang positif, adalah patut disyukuri bahwa seluruh peserta kuliah stukon4 tahun 2015 ini sebanyak $86 \%$ menyukai bentuk pembelajaran SCL, artinya kalaupun masih ada yang belum merupakan langkah selanjutnya yang harus dipersiapakan dan kedua untuk angkatan baru, walau dalam data sebelumnya mereka tidak tahu arti SCL, namun pada pertanyaan selanjutnya (setelah diberikan pemahaman), ternyata terdapat peningkatan $20 \%$ mereka menyukai pembelajaran SCL, hanya saja itupun pada gender laki-laki. Kenapa gender perempuan tidak suka? Dan berikutnya, semoga indikasi suka pembelajaran SCL ini tidak semata pada matakuliah strukon4 saja.

Sedangkan hal yang negative adalah data mengungkapkan bahwa bertambahnya lama pendidikan yang telah ditempuh/dilewati di jurusan arsitektur (data dari angkatan 2013 dan 2012), ternyata tidak signifikan mereka sudah tahu tapi tidak sepenuhnya menyukai pembelajaran SCL, untuk angkatan 2013 hanya 50\% dan angkatan 2012 hanya 86\%. Dan kembalilagi data mengungkapkan bahwa gender perempuan lebih tinggi prosentasenya untuk tidak menyukai pembelajaran SCL ini : 83\% untuk angkatan 2013 dan 67\% untuk angkatan 2012). Kenapa gender perempuan tidak menyukai pembelajaran alan SCL ini ?

Para mahasiswa/i Jurusan Arsitektur dominasi menyukai pembelajaran dengan model SCL, kecuali gender perempuan?

\section{KESIMPULAN}

Peminat pendidikan arsitektur Undip dari tahun ke tahun selalu meningkat, bahkan hingga ditahun 2015 ini saja tiap angkatan selalu menerima mahasiswa diatas 140 mahasiswa. Hal yang menarik perlu disampaikan disini, bahwa prosentase gender laki-laki dan perempuan dibandig tahun 1980an (25 tahun yang lalu) kini berbanding terbalik. Dulu gender perempuan diantara 70 mahasiswa tidak lebih dari 15 mahasiswi atau sekitar $20 \%$, namun ditahun 2000an ini, dalam satu kelas pengikut matakuliah strukon saja tercatat $60 \%$ gender perempuan. Sejauh mana kemampuan mereka dalam mengikuti perkuliahan struktur dan konstruksi dan kesiapan serta pemahaman terhadap modelpembelajaran SCL terhadap matakuliah struktur?

Silabus matakuliah struktur dari serangkaian perkulihan di JAFT dari semester 01 hingga 06, sebenarnya telah disusun secara sistematis dan berjenjag tingkat pemahaman dan kesulitannya serta kompleksitas subtansinya. Tapi semenjak beberapa tahun ini, pengambilan matakuliah struktur tidak lagi pre-req sebagaimana matakuliah Perancngan Arsitektur (PA), sehingga yang terjadi pada matakuliah strukkon 4/ struktur konstruksi semester 04 inisaja bisa diambil oleh mahasiswa yang baru semester 02. Rtinya dalam satu semester ini, mereka mengambil 2 matakuliah struktur pada jenjang/semester yang berbeda dan tentunya tingkat kesulitannya berbeda. Apakah hal ini mempengaruhi prestasi mereka atau justru disinilah letak kemampuan mereka dalam 'melahap' semua matakuliah secara bersamaan. Semoga effek samping tidaklah mempengaruhi penilaian matakulaih tertentu dengan dalih terlalu berat atau terlalu banyak tugas.

Tingkat pemahaman metode SCL dalam penelitian ini membuktikan bahwa lama studi mempengaruhi tingkat pemahaman SCL. Diawali sebatas singkatan.

\section{Daftar Pustaka}

Direktorat Akademik - Direktorat Jenderal Pendidikan Tinggi (2008), Buku Panduan Pengembangan Kurikulum Berbasis Kopetensi Pendidikan Tinggi (sebuah Alternatif Penyusunan Kurikulum). Jakarta:

Direktorat Jenderal Cipta Karya Departemen Pekerjaan Umum, (1997). Pedoman Teknis Pembangunan Gedung Negara.

Lippsmeier, Georg., (1994), Bangunan Tropis, Erlangga, Jakarta.

LP2MP Undip, (2014), Bahan Workshop dan Pelatihan Model pembelajaran, tahun 2014

Menteri Permukiman dan Prasarana Wilayah,(2002). Pedoman Teknis Pembangunan Bangunan Gedung Negara.. Departemen permukiman dan Prasarana Wilayah Peraturan Akademik Undip Bid. PendidikanNo. 209 thn. 2012

Prianto, E.,(2007), Rumah Tropis Hemat Energi Bentuk Keperdulian Global Warming, Jurnal Pembangunan Kota Semarang RIPTEK, Vol.1, No.1, Semarang, Hal 1-10.

Satwiko, P. (2005). Arsitektur Sadar Energi. Penerbit Andi, Yogyakarta.

Soegijanto, (1998), Bangunan Di Indonesia Dengan Iklim Tropis Lembab Ditinjau Dari Aspek Fisika Bangunan, Direktorat Jendral Pendidikan Tinggi, Departemen Pendidikan Dan Kebudayaan.

Szokolay S.V., (1980), Environmental Science Handbook, The Constructions Press Ltd, England.. 